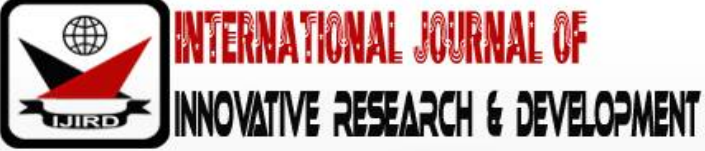

ISSN 2278 - 0211 (Online)

\section{Corporal Punishment as a Strategy for Managing Behaviour: Perspectives of Children of Inclusive Schools in Ghana}

\section{Emmanuel Tawiah Aboagye}

Assistant Test Administration Secretary, Department of Ministry of Education

National Board for Professional and Technician Examinations (NABPTEX),Ghana

\begin{abstract}
:
Discipline is about correcting children's behaviour and helping them make informed decisions. The manner some educators, teachers and parents often choose to discipline children is complicated. Children opinion about these disciplinary measures cannot be overemphasized. The problem is that some teachers still resort to corporal punishment in the classroom in schools in Ghana as at the time this research was being conducted. Some parents and teachers still support corporal punishment. The objective for conducting this study, was to find out how children think about the use of corporal punishment as a strategy in managing their behaviour. This is a concern for educational practitioners in Ghana and the world at large. Children in the Junior High Schools in Ghana took part in this study. In all, 636 school children in inclusive schools were involved in the study. The study revealed that, some children were of the view that excessive use of the corporal punishment causes disrespect, aggressiveness, sickness and indiscipline. On the other hand, some of the children think that corporal punishment put fear in children and makes them very timid. It again makes students hate their teachers and parents; feel angry and belittled. The study concluded that corporal punishment does not totally eliminate bad behaviour and it can lead to death of a students. Some teachers do it excessively and its application is abused. The children think that when they feel loved they are drawn closer to their parents, teachers and educators when they need help or advice. The implication to the policy is that Corporal punishment should not be encouraged in schools in Ghana.
\end{abstract}

Keywords: Corporal punishment, strategy, behaviour, teachers and children

\section{Introduction}

School discipline means an arrangement consisting of code of conduct, punishment and behavioural strategies to regulate school children and to make school and classroom conducive for learning. The purpose of classroom management and discipline is controlling children actions, habits, attitude and behaviour in the classroom. Positive discipline in schools involves the maintenance of a climate that is highly conducive for learning (Farooq, 2014). Corporal punishment includes a wide range of disciplinary procedures that are employed as a negative reinforcement to change behaviour. Corporal punishment is 'the use of physical force with the intention of causing a child to experience pain, but not injury, for the purpose of correcting or controlling the child's behaviour' (Donnelly and Straus, 2005). The expression "pain, but not injury" aids to differentiate corporal punishment from physical abuse. Corporal punishment includes spanking, a method used by $65 \%$ of parents of young children in the United States. Although a majority of parents in the study reported using corporal punishment as a behaviour modification technique, most would have rather preferred using other means for behavioural management and discipline (American Academy of Child \& Adolescent Psychiatry, 2019). School corporal punishment is usually executed in the form of "paddling," or striking the children with a wooden or fiberglass paddle on their buttocks or legs. This can cause physical injury like abrasions, bruising, severe muscle injury, hematoma, whiplash damage, life-threatening haemorrhages, and other medical complications that call for doctor's attention hospitalization (DeNies, 2012). Corporal punishment by parents is legally sanctioned in 166 countries. The bodily punishment of children with kits such as paddles is permitted in 81 countries including United States (Lenta, 2012). Physical punishment is limited to paddling or other spanking in most States that allow it. In this case all the schools have rules about how they can administer corporal punishment and for what offenses (Rollins, 2012).

Discipline is about helping children to make good decisions and to develop proper control of their lives and relationships with other people. There are debates about styles of discipline in Ghana and many other countries. Most parents, teachers, educationist, adults in the developing world and particularly in Ghana believe that corporal punishment work on children who are indiscipline.

Extensive research has shown that despite corporal punishment has great impact on modifying immediate behaviour it is ineffective over time. This is because it leads to aggression as well as reduces the moral internalization of a child's appropriate behaviour. Other negative consequences of corporal punishment include experiencing physical and emotional pain, which negatively affect learning capacity. The child being less likely to learn why a certain behaviours or 
action were wrong. The child may behave out of fear in the future. It may increase risk for physical abuse and the possibility that, the child learning that aggression is an acceptable method of problem solving (American Academy of Child \& Adolescent Psychiatry, 2019).

Some teachers still use corporal punishment in school though banned by the Ministry of Education and the Ghana Education Service. Research conducted by Agbenyega (2006) in Ghana, reported that corporal punishment still persists in both school sites at relatively the same scale. Most teachers and parents use punishment to correct disobedience.

Children voices are very important because most of the time parents and teachers make decisions which affect the future of children. Children therefore need to have a say in some of the policy decisions that bring about changes in their lives. Solutions to problems of emotional and behaviour difficulties of children are professionally demanding because teachers without knowledge in behaviour management skills find it difficult to manage undesirable behaviours in schools and classrooms.

\subsection{Argument for and against Corporal Punishment}

The mainstream inclusion of pupils who have emotional and behavioural difficulties presents a challenge to teachers and other related staff in schools. As Salmon (2006) argued, because of the frequency of these behaviours, teachers often become frustrated when handling problematic situations. Some authors, like Benatar (1998) feel corporal punishment can be right or wrong. Others say psychological punishments are harsh, too, but in a different way. In most communities in Ghana "beating" is a generic term for any corporal punishment. To some parents "spanking" means slapping a child on the buttocks. For middle-class Americans, it tends to be a generic term for slapping or hitting any part of the child. 'Whatever the ambiguities in how we think and talk about corporal punishment, the overwhelming majority of adult Americans approve of it. Many regard corporal punishments positively as a customary and necessary technique of child rearing, and almost everyone believes that it may be necessary at least as a punishment of last resort'. (Donelly and Straus, 2005).

Most adults in children life and parents seem to believe that corporal punishment adds to serve as an implement for influencing the child's behaviour. Many education specialists now believe that this tool is less effective, and that it carries with it many unproductive side effects. Thus, the value of hitting as a positive teaching strategy is quite limited, and its costs as a negative teaching strategy is quite high. It certainly diminishes the partnership nature of the socialization process and may lead to the extremely costly "error" of psychological maltreatment (Garbarino, Guttmann, and Seeley 1986). Firstly, Benatar (1998) focuses on one form of corporal punishment, defined as "the infliction of physical pain without injury." Benatar argued from the hedonistic premise that the infliction of pain is morally wrong and to be avoided all things must be considered. With this in mind, then, how do the arguments against the practice be fair? Some also claim that corporal punishment leads to abuse since its infliction of physical pain does not necessarily cause injury to children. This abuse is common among some parents. Despite the fact that several things can be abused by people, it does not mean that it should be banned outright by the public. Instead of condemning the non-abusive use of corporal punishment, it is imperative to condemn the abusive use of corporal punishment (Benatar, 1998).

Another argument against corporal punishment is that it is psychologically damaging to children. Corporal punishment adversely affects a child's self-image and school achievement. It can also lead to disruptive and violent behaviour in children (Kilimci, 2009). This means that if teachers, administrators and parents/ guardians use corporal punishment in the name of discipline, then it could imply that they are also contributors to many misbehaviours and aggression in school children. Benatar (1998) also added that while there is evidence that excessive or harsh corporal punishment can have such effects, it is not at all clear what mild and infrequent corporal punishment do. The Psychiatric News (as cited in Cryan, 1995) states that the psychological effects may be as harmful as the physical effects. The review shows that corporal punishment may adversely affect a child in several ways. This may include the student's self-image, academic and other school achievement. Many violent and disruptive behaviours of many difficult children could be that corporal punishment is a contributing factor. Therefore, corporal punishment simply does not work since it does not deter children from bad behaviour.

\subsection{Effectiveness of Corporal Punishment}

In the field of behavioural disorders, a concern is the lack of correspondence between what is known about effective practices and what practices young children with challenging behaviour typically receive in terms of support. Most teachers in the developing world have simple ways of dealing with these children, by punishing them, threatening them, excluding the children from school or subjecting them to severe beating. The abuse of children is against child's right. Robinson et al (2005) question the effectiveness of corporal punishment and underline the side effects of corporal punishment such as running away, fear of teacher, feelings of helplessness, humiliation, aggression and destruction at home and at school, abuse and criminal activities. Gershoff (2002) also attributes corporal punishment to increased aggression and lower levels of moral internalization and mental health and adds that adults who were corporally punished when children are more likely to be criminals, be violent with their sexual partner, and spank their own children.

\subsection{Discipline of Children}

Whatever ways teachers and parents think, they need to be very clear about how children should be disciplined. Parents and other adults need to agree on how children should be disciplined in a consistent and reasonable way. Many children in basic schools and Seniors High Schools are disciplined in an inappropriate manner because most adults including the teachers and the other stakeholders in education do not have enough information about behaviour management strategies. Children are excluded from schools and one does not care whether they end up as armed robbers 
or not. A child is caught stealing from schools and he is excluded to continue stealing at home without solving his/her problem. We brand children as lazy without finding the reasons of the laziness and to help them to solve their problems. As Cooper indicated, Exclusion is not a constructive, educational intervention. Rather it is an unambiguous statement of the school's failure to accommodate the excluded student. Furthermore, it reinforces and provokes negative attitudes towards schools and schooling among those excluded (Cooper et al., cited in Cooper \& Jacobs 2011).

\subsection{Support for Difficult Children}

Children and youth with emotional disturbance frequently require support in the form of services from a variety of agencies. These young people are also quite diverse in terms of their needs and strengths. Some children present complex ranges of disabilities, from conduct disorder to schizophrenia. A review of the literature by Bal (n.d) indicates that 3 to 5 years of leaving school, 48 percent of young women with emotional disturbance were mothers, as compared to 28 per cent of young women with other disabilities. Fifty-eight per cent of the students with emotional disturbance had been arrested, versus 19 per cent of those with other disabilities. Also, 10 per cent of youth with emotional disturbance were living in a correctional facility, halfway house, drug treatment centre, or "on the street"--twice as many as among the students with other disabilities (Wagner, 1995; Wagner, Blackorby, Cameto, Hebbeler, \& Newman, 1993) by the Eligibility Services.

Jenson, Reavis and Rhode (1998) point to the need for positive support for the difficult student because they usually have a history of punishment to which they have grown immune and according to them, permanent behaviour changes of such children are maintained only by basic positive procedures. Successful programs for students with emotional and behaviour difficulties depend on contributions, effort, involvement, and commitment from teachers who possess specialized skills to work effectively with students who exhibit academic and behavioral deficits (George et al., 1995). The effective academic instruction for students with EBD requires assessments of students' interests and abilities. The teachers and other educators of children with emotional and behaviour difficulties need to provide academic instructions that address multiple intelligences, diverse learning styles and also provide opportunities for real life applications to ensure relevance for each EBD child (Abrams, 2005).

\section{Methodology}

There is an increasing need to ascertain the effective way of managing behaviour in the classroom especially that of inclusive schools. The need to implement effectively inclusive education in Ghana by Ghana Education Service as well as part of the Strategic Development Goals lead to the selection of students in inclusive schools.

\subsection{Research Design}

The research design used is descriptive survey coupled with the used of questionnaires to gather responses from students. The study also made used of both qualitative and quantitative methods in analyzing data collected. Ethical issues on the methods regarding data collection was considered carefully. The children were assured of the confidentiality of the data collected from them.

\subsection{Population and Sample}

The population consist of all the inclusive schools in the four selected regions in Ghana. As at the time the data was collected there were ten (10) regions in Ghana. The study involved 636 students in inclusive schools selected from four regions in Ghana. The aim of selecting children from inclusive schools is that the inclusive policy being implemented by the Ministry of Education, Ghana, focuses primarily on improving education of the students with Special Education Needs in inclusive schools of which children with emotional and behaviour difficulties cannot be excluded in the inclusion policy. Children in inclusive schools are expected to provide an unadulterated view on whether corporal punishment is a strategy for managing behaviour in inclusive schools.

\subsection{Data Collection Tool and Procedure}

For the purpose of this research Likert scale questions were developed and used for the data collection. The questionnaire was pre-tested before the final distribution to the students. The questionnaire meant for pre-testing was given to inclusive schools under Accra Metropolitan Education office. The schools selected were inclusive basic public school where the respondents were mainly from Junior High Schools. This was meant to check for clarity of the questions, whether the questionnaire covers the areas supposed to cover and also to check for face validation and the reliability of the questions.

\subsection{Analysis and Discussion}

The quantitative data gathered was analyzed using Scientific Package for Social Science (SPSS) computer software. Percentages and ranks were used to analyse the children view on the use of corporal punishment as a strategy for managing behaviour in inclusive schools. The demographic of respondents' (students) profile information is presented in Table 1. 


\begin{tabular}{|c|c|c|}
\hline Sex & Number of Students & Percent of Students \\
\hline Male & 283 & 44.5 \\
\hline Female & 353 & 55.5 \\
\hline Total & 636 & 100.0 \\
\hline
\end{tabular}

Table 1: Gender Distribution of Children

Source: Field Data 2016

Table 1 shows the gender distribution of children involved in the study. Out of a total of 636, the gender composition was 283(44.5\%) for male and 353 (55.5\%) for female.

Table 2 shows the category of people the children live with. Out of 636 of the children involved in the study, majority of them numbering 326 (51.3\%) are living with both parents. Children numbering 155(24.4\%) are living with mother only but $42(6.6 \%)$ are living with father only. A total number of 27(4.2\%) students leave with adopted parent and $84(13.2 \%)$ of them leave with sibling or relative. Few children numbering $2(0.3 \%)$ leave alone. The categorization is very important because knowing the category of parents or carers, the children live with gives enough background information about how to manage these children.

\begin{tabular}{|c|c|c|}
\hline Guardian of Students & Number of Students & Percent \\
\hline Both Parents & 326 & 51.3 \\
\hline Mother only & 155 & 24.4 \\
\hline Father only & 42 & 6.6 \\
\hline Adopted Parent & 27 & 4.2 \\
\hline Sibling/ Relative & 84 & 13.2 \\
\hline Alone & 2 & 0.3 \\
\hline Total & 636 & 100.0 \\
\hline
\end{tabular}

Table 2: The category of people the children are living with

Source: Field data 2016

\subsubsection{Corporal Punishment}

On the use of corporal punishment children's views were collected and the analysis is shown in Table 3 . The children gave several reasons why teachers use corporal punishment.

\begin{tabular}{|c|c|c|c|}
\hline Reasons & $\begin{array}{c}\text { Number of } \\
\text { Responses }\end{array}$ & $\begin{array}{c}\text { Percentage of Number of } \\
\text { Responses }\end{array}$ & Ranking \\
\hline Refusal to do homework & 350 & 55.0 & 1.5 \\
\hline $\begin{array}{c}\text { Students who do not show } \\
\text { respect. }\end{array}$ & 70 & 11.0 & 8 \\
\hline Submitting assignment late. & 100 & 15.7 & 5.5 \\
\hline Absent without permission. & 90 & 14.1 & 7 \\
\hline $\begin{array}{c}\text { Wearing uniform which is not } \\
\text { prescribed by the school. }\end{array}$ & 60 & 9.4 & 3 \\
\hline Students cheating in examination. & 250 & 39.3 & 4 \\
\hline Eating in class. & 170 & 26.7 & 5.5 \\
\hline Uncleanliness. & 100 & 15.7 & 1.5 \\
\hline Coming to school late & 350 & 55.0 & 3 \\
\hline
\end{tabular}

Table 3: Reasons for Using Corporal Punishment Stated by Children Source: Field Data 2016

It is obvious from Table 4 that an overwhelming number of children said that they receive corporal punishment when they come to school late and refuse to do their homework/ exercise. This is backed with a total response of 350, ranking 1.5. This is then followed by 250 responses with a ranking of 3 indicating that students are punished when they cheat in examination. A ranking of 4 representing 170 responses shows that students who eat in class are punished. A total response of 100 with a ranking of 5.5 reveal that students are also punished for uncleanliness and late submission of assignment. Students who do not respect as well as wear dress which are not prescribed to school are also punished. Table 4 reveals this indicating a total response of 70 and 60 with a ranking of 8 and 9 respectively. 


\begin{tabular}{|c|c|c|}
\hline Reasons & Number of Responses & Ranking \\
\hline Humans should not be beaten. & 110 & 5 \\
\hline $\begin{array}{l}\text { The child can be injured which can cause } \\
\text { permanent disability. }\end{array}$ & 200 & 1 \\
\hline It is against the law. & 50 & 8.5 \\
\hline $\begin{array}{c}\text { It makes children feel unhappy and run away from } \\
\text { home or school. }\end{array}$ & 150 & 3 \\
\hline It does not totally eliminate bad behaviour. & 50 & 8.5 \\
\hline $\begin{array}{l}\text { It makes offenders hardened when used } \\
\text { excessively. }\end{array}$ & 25 & 11 \\
\hline It puts fear in the child. & 170 & 2 \\
\hline $\begin{array}{l}\text { Children know what they should do so they should } \\
\text { not be beaten. }\end{array}$ & 15 & 12 \\
\hline Beating for no reason causes the child to rebel. & 51 & 7 \\
\hline $\begin{array}{l}\text { Other means of managing children should be } \\
\text { considered. }\end{array}$ & 125 & 4 \\
\hline It is biblical to train the child. & 10 & 13 \\
\hline The children do not see why they should be beaten. & 75 & 6 \\
\hline The child can die. & 30 & 10 \\
\hline
\end{tabular}

Table 4 : Why Children Think Corporal Punishment Should Be Abolished at Home Source: Field Data 2016

Table 4 indicates that majority of the children with a total response of 200 and ranking of 1 said that beating at home can cause injury to a child leading to permanent disability. A total response of 170 with a rank of 2 indicated that beating at home puts fear in the child. Some of them also said that beating makes children feel unhappy and run away from home. This is evident in Table 4 with a total response of 150 having a rank of 3. A rank of 4 representing 125 responses shows that children think beating at home or school should be abolished and other means should be considered. The children also said humans should not be beaten while others do not see why they should be beaten. This is backed with a ranking of 5 and 6 representing a total response of 110 and 75 respectively. Beating for no reason causes the child to rebel recorded a total response of 51 and ranking of 7 . The children also confirmed that beating at home is against the law and does not totally eliminate bad behaviour. A ranking of 8.5 and total responses of 50 confirms this. Moreover, the children indicated that a child can die out of beating and beating makes offenders hardened when done excessively. This is evident in Table 4 with the former having a ranking of 10 and 30 responses and the latter having a ranking of 11 and 25 responses. A total response of 15 with a ranking of 12 reveals that children know what they should do but few children with a total response of 10 representing a rank of 13 agreed that beating is a biblical way to train a child. It is obvious that responses of the children confirm the assertion of Benatar (1998) that harsh corporal punishment can have effect like depression and anxiety in children. The children's responses also support the view that corporal punishment leads to running away from school, fear of teacher, feelings of helplessness, humiliation, aggression and destruction at home and at school, abuse and criminal activities (Robinson et al,2005).

\subsubsection{Why Do You Think Corporal Punishment Should Not Be Abolished at Home?}

On the other hand, some students indicated that beating is good because it helps them to do the right thing. It is used to check discipline and prevent bad behaviour from occurring. Some of the children believe that it is written in the bible that children should be beaten so that they do become difficult children. Some also think that beating is alright for children but excessive use of the stick causes disrespect, aggressiveness, sickness and indiscipline.

\begin{tabular}{|c|c|c|}
\hline Reasons & $\begin{array}{c}\text { Number of } \\
\text { Responses }\end{array}$ & Ranking \\
\hline It helps us to do the right thing & 50 & 5 \\
\hline It is used to correct indiscipline & 20 & 8 \\
\hline It prevents bad behaviour from occurring & 60 & 3 \\
\hline It is biblical & 110 & 1 \\
\hline It prevents repetition of inappropriate or bad behaviour & 17 & 9 \\
\hline It helps the children become responsible and improve behaviour & 25 & 7 \\
\hline $\begin{array}{c}\text { It helps children to learn good behaviour and it is a good tool for } \\
\text { checking inappropriate behaviour }\end{array}$ & 35 & 6 \\
\hline Other measures should be considered inclusively & 65 & 2 \\
\hline $\begin{array}{c}\text { Excessive use of the cane causes disrespect, aggressiveness, } \\
\text { impetuous and indiscipline. }\end{array}$ & 10 & 10 \\
\hline It makes the child committed and learns from mistakes & 55 & 4 \\
\hline Tabo 5 .
\end{tabular}

Table 5: Why Children Think Corporal Punishment Should Be Not Abolished at Home Source: Field Data 2016 
A rank of 1 with a total response of 110 reveals that majority of the children agreed that beating is good because it is biblical. According to the children other measures should be considered apart from the use of the cane which is supported with a total response of 65 and a rank of 2 . The children also said that beating at home prevents bad behaviour from occurring. This is indicated in Table 5 with a rank of 3 representing 60 responses. Some children also think that beating makes the child committed to whatever task is set for him/ her and learn from mistakes but others think it helps them to do the right thing. This is supported by a total response of 55 and 50 having a ranking of 4 and 5 respectively. This is followed by a total response of 35(rank of 6 ) indicating that beating helps children to learn from good behaviour and it is a good tool for checking inappropriate behaviour. Beating also makes children become responsible and improve behaviour which is confirmed by a ranking of 7 representing 25 responses. The children further said that beating is used to correct indiscipline representing a total response of 20 and a rank of 8 . A total response of 17(rank of 9) indicates that children think that beating prevents repetition of inappropriate behaviour but few of them with a total response 10 (rank of 10) think that beating can cause a child to die. It could be deduced form the analysis that some children have been made to understand that beating is good.

\subsubsection{How Children Feel When They Are Punished by Parents and/ or Teachers}

When the children were asked to express their views on how they feel when beaten. It was revealed that children generally are not happy when beaten by parents or teachers. Many students feel that beating is not good because it causes pain and can make children fall sick. Children need to be happy but according to the students beating makes them unhappy. It rather put fear in children and makes them very timid. It again makes students hates their teachers and parents and feel angry at their teachers and parents. This makes Robinson et al (2005) question the effectiveness of corporal punishment and underline the side effects of corporal punishment such as running away, fear of teacher, feelings of helplessness, humiliation, aggression and destruction at home and at school, abuse and criminal activities.

\begin{tabular}{|c|c|c|}
\hline & $\begin{array}{c}\text { Number of } \\
\text { Responses }\end{array}$ & Ranking \\
\hline $\begin{array}{c}\text { It causes pain/ injury and can fall sick. } \\
\text { It makes the child unhappy. }\end{array}$ & 125 & 2 \\
\hline $\begin{array}{c}\text { parents. } \\
\text { It puts fear in the child and makes the child timid. }\end{array}$ & 120 & 3 \\
\hline $\begin{array}{c}\text { It makes the child feel hatred or nnger for the teacher or } \\
\text { It makes the child committed and learns from mistakes. }\end{array}$ & 60 & 7 \\
\hline It makes the child feel ashamed or uncomfortable. & 112 & 5 \\
\hline It makes the child nervous, furious and anxious. & 10 & 17 \\
\hline It prevents the child from going to his/ her class & 30 & 13 \\
\hline It makes the child think he/ she is being hated. & 20 & 16 \\
\hline Excessive use of the cane makes the child stubborn. & 30 & 13 \\
\hline It makes the child feel he/ she is not a human being. & 50 & 8 \\
\hline $\begin{array}{c}\text { It makes the child feel bad when teachers or parents don't } \\
\text { listen to his/ her explanations. }\end{array}$ & 70 & 6 \\
\hline $\begin{array}{c}\text { It makes the child angry because he/ she doesn't know the } \\
\text { reason why he/ she is being beaten. }\end{array}$ & 35 & 11 \\
\hline It makes the child feel bad/ sorry and offended. & 30 & 13 \\
\hline It makes the child confused and disturbed. & 45 & 9 \\
\hline It indicates love for the children. & 2 & 18 \\
\hline $\begin{array}{c}\text { It makes the child aggressive and bad ideas come on his/ her } \\
\text { mind. }\end{array}$ & 40 & 10 \\
\hline $\begin{array}{c}\text { The child feels bad for things done unintentionally and still } \\
\text { beaten. }\end{array}$ & 21 & 15 \\
\hline
\end{tabular}

Table 6: How the Students Feel When They Are Beaten by Parents and/ or Teachers Source: Field Data 2016

It is obvious from Table 6 that many children feel unhappy when beaten by parents and teachers representing a total response of 150 and ranking of 1 . This is followed by the assertion that beating causes pain/injury and can make them fall sick. A total response of 125 with a rank of 2 confirms this and responses numbering 120 (rank of 3 ) indicate that beating children puts fear in them and makes them timid. Table 6 indicates that children feel ashamed and uncomfortable due to beating. This is supported by a total response of 112 which is ranked 4. Beating also makes children committed and learns from mistakes representing a total response of 92 with a ranking of 5. Responses numbering 70 with a rank of 6 confirms that children feel bad when teachers or parents do not listen to their explanations. The children also said that they feel hatred for their teachers or parent when beaten. A response of 60 with a ranking of 7 confirms this and a ranking of 8 ( 50 responses) confirm that beating children makes them feel like they are not human. Moreover, the children become confused and disturbed when beaten representing a total response of 45 with a rank of 9 . Responses numbering 40 representing a rank of 10 shows that children became aggressive and have bad ideas in the mind due to beating. Some children also confirm that they became angry because they do not know the reason why they are being beaten. This 
assertion is confirmed by a total response of 35 with a rank of 11 . The children again said that beating prevents them from going to their class, makes them feel bad and offended as well as makes them stubborn. Table 6 supports this with a total response of 30 having a rank of 13. The children also stated that beating makes them feel bad for things they do unintentionally as well as makes them think they are being hated. The former assertion has a total response of 21(rank of 15) and the latter having a total response of 20 (rank of 16). Responses numbering 10(rank of 17) shows that children became nervous, furious and anxious when beaten by parents or teachers. On the contrary, few of the respondent numbering 2(rank of 18) shows that most of the children think that beating them does not indicate love for them.

\subsubsection{Reason Why Corporal Punishment should be abolished in Schools}

The students involved in the study expressed many reasons why corporal punishment should be abolished in schools as shown in Table 7. The students indicated that corporal punishment causes pain and affect the children mentally. It rather causes truancy, discourages attendance and causes laziness. This confirms with what American Academy of Child \& Adolescent Psychiatry (2019) indicated that corporal punishment may increase risk for physical abuse and the possibility that, the child learning that aggression is an acceptable method of problem solving. To the respondents, corporal punishment does not totally eliminate bad behaviour and it can lead to death of a students. When children feel loved they are drawn closer to the teacher when that child needs help or advice. This help the child to learn better. The students mentioned corporal punishment is not an appropriated tool and that other measures must be considered to be abolished. The respondent further indicated further indicated that corporal punishment sometimes creates problems between children, teachers and parents. The students involved in the study believed that some teachers do not know about psychological development of children.

\begin{tabular}{|c|c|c|c|}
\hline $\begin{array}{c}\text { Why Corporal Punishment Should Be } \\
\text { Abolished }\end{array}$ & Number of Responses & $\begin{array}{c}\text { Percentage of } \\
\text { Responses }\end{array}$ & Ranking \\
\hline $\begin{array}{c}\text { It causes physical injury and affects the } \\
\text { child mentally. }\end{array}$ & 180 & 15.1 & 1 \\
\hline $\begin{array}{c}\text { It causes truancy and discourages school } \\
\text { attendance. }\end{array}$ & 160 & 13.5 & 10 \\
\hline $\begin{array}{c}\text { It makes the child uncomfortable and } \\
\text { puts fear in them. }\end{array}$ & 51 & 4.4 & 9 \\
\hline $\begin{array}{c}\text { It does not totally eliminate bad } \\
\text { behaviour. }\end{array}$ & 52 & 4.2 & 11 \\
\hline $\begin{array}{c}\text { It can lead to death. } \\
\text { It is done excessively or it is abused. } \\
\text { teacher when the child needs help or } \\
\text { advice and is able to learn better. }\end{array}$ & 50 & 5.6 & 7 \\
\hline $\begin{array}{c}\text { It is not an appropriate tool and other } \\
\text { measures should be considered. e.g. } \\
\text { Counselling }\end{array}$ & 66 & 10.6 & 3 \\
\hline $\begin{array}{c}\text { It kills the can-do spirit of the child/ } \\
\text { individual interest. }\end{array}$ & 126 & 2.5 & 13 \\
\hline $\begin{array}{c}\text { It can create problems between teachers } \\
\text { and parents. }\end{array}$ & 30 & 10.0 & 15 \\
\hline $\begin{array}{c}\text { To prevent the child from being } \\
\text { aggressive and controversial. }\end{array}$ & 120 & 1.7 & 6 \\
\hline Some teachers beat children for fun. & 20 & 6.7 & 14 \\
\hline $\begin{array}{c}\text { Some teachers do not know the } \\
\text { psychological development of the child. }\end{array}$ & 25 & 2.1 & 5 \\
\hline $\begin{array}{c}\text { It leads to hatred by the children. } \\
\text { and therefore children should not be } \\
\text { punished. }\end{array}$ & 115 & 9.7 & 12 \\
\hline
\end{tabular}

Table 7: Why Corporal Punishment Should Be Abolished in Schools? Source: Field Data 2016

Table 7 displays the reason given by children on the need to abolish corporal punishment in schools. An overwhelming number of children indicated that beating cause physical injury and affects them mentally. This assertion as shown in Table 7 has a total response of 180 and a ranking of 1 . This is then followed by the assertion of children that beating in schools causes truancy and discourages school attendance recording a total response of 160 which is ranked 2. Also, responses numbering 126(rank of 3) shows that beating is not an appropriate tool and other measures should be considered for example counselling. A total response of 120 and 115 with a rank of 4 and 5 respectively indicates that beating creates problems between teachers and parents and also leads to hatred for the child. Some children said that 
teachers beat for fun and this is supported with 80 responses (rank of 6). Others also said that beating in schools should be abolished in order to draw the child closer to their teachers when they need help or advice. This is supported by a total response of 69 having a rank of 7. A rank of 8 representing a total response of 66 shows that children think beating is excessive in schools hence being abused.

\subsubsection{Why Corporal Punishment Should Not Be Abolished in Schools?}

Few reasons were given by the children to explain their intention why corporal punishment should not be abolished. The reasons are shown in Table 8.

\begin{tabular}{|c|c|c|c|}
\hline & $\begin{array}{c}\text { Number of } \\
\text { Responses }\end{array}$ & $\begin{array}{c}\text { Percentage } \\
\text { of Responses }\end{array}$ & Ranking \\
\hline $\begin{array}{c}\text { It makes children behaviour well, without it } \\
\text { there will be indiscipline, truancy, etc. }\end{array}$ & 30 & 22.2 & 1 \\
\hline $\begin{array}{c}\text { It makes the child responsible and does the right } \\
\text { thing. }\end{array}$ & 20 & 14.8 & 2 \\
\hline $\begin{array}{c}\text { The child learns from the mistakes. } \\
\begin{array}{c}\text { It prevents the child from doing bad or } \\
\text { repeating bad behaviour. }\end{array}\end{array}$ & 10 & 7.4 & 6 \\
\hline It is a tool for correcting bad behaviour. & 15 & 11.1 & 3 \\
\hline It serves as a deterrent. & 14 & 8.9 & 5 \\
\hline $\begin{array}{c}\text { It prevents the child from putting up bad } \\
\text { behaviour. }\end{array}$ & 8 & 5.9 & 4 \\
\hline
\end{tabular}

Table 8: Why Corporal Punishment Should Not Be Abolished in Schools? Source: Field Data 2016

Table 8 shows the reasons why children think corporal punishment should not be abolished in schools. The highest responses were recorded by the assertion that absence of corporal punishment promotes bad behaviour such as indiscipline or truancy. A total response of 30 having a ranking of 1 reveals this as shown in Table 8. Next is the assertion that corporal punishment makes the child responsible and does the right thing and this is supported by a total of 20 responses (rank of 2). Responses numbering 15 with rank 3 means that corporal punishment prevents the child from repeating bad behaviour. Furthermore, respondents also asserted that corporal punishment serves as a deterrent representing a total response of 14 (4 as rank). Some of the respondents numbering 12(rank of 5) think corporal punishment is a tool for correcting bad behaviour but others numbering 10(rank of 6) think the use of corporal punishment makes children learn from their mistakes. The use of corporal punishment prevents the child from putting up bad behaviour recorded the least responses of 8(rank of 7).

\subsubsection{What Do You Want to Say to Your Parents or Teachers Regarding How They Should Manage Bad Behaviour}

In answering the question, what do you want to say to your parents and teachers regarding how they should manage bad behaviour. The children indicated that parents/ teachers should not punish them but rather give them advice, they should have patience on them and always talk to them.

\begin{tabular}{|c|c|c|}
\hline & Number of Responses & Ranking \\
\hline They should advice the child. & 50 & 5.5 \\
\hline They should punish the child. & 25 & 11.5 \\
\hline They should have patience on children with EBD. & 125 & 3 \\
\hline They should manage the bad behaviour. & 150 & 2 \\
\hline They should have love for the child. & 200 & 1 \\
\hline They should train the child. & 50 & 5.5 \\
\hline They should recognize bad behaviour immediately. & 10 & 16.5 \\
\hline They should counsel the child or promote counselling. & 6 & 18 \\
\hline They should have equal treatment for all children. & 10 & 16.5 \\
\hline Warning should be given before punishment. & 20 & 13.5 \\
\hline Parents or teachers should be careful when punishing & 40 & 8 \\
\hline children. & & 11.5 \\
\hline They must communicate with the children. & 25 & 15 \\
\hline They should not insult children. & 16 & 8 \\
\hline They should provide the need of the child. & 40 & 10 \\
\hline They should serve as a role model. & 35 & 13.5 \\
\hline They should learn to forgive children. & 20 & 4 \\
\hline They should not keep quite. & 60 & 8 \\
\hline They should tell the children motivational stories. & 40 & \\
\hline Tale & & \\
\hline
\end{tabular}

Table 9: Children Views on How Parents Should Manage Their Bad Behaviour Source: Field Data 2016 
According to the children, instead of using corporal punishment to manage their bad behaviour, parent should rather show them love. This is evident in Table 9, showing the highest response of 120 with a rank of 1 . This is then followed by the assertion that parent should manage their behaviour using other methods other than the use of cane. A total response of 150 and a rank of 2 affirm this. Responses numbering 125 with a rank 3 shows that parents should have patience with EBD children. The children also said parent must not keep quite when their children have emotional and behaviour difficulties. This is supported by a total response of 60 and a rank of 4 . The same number of responses (50) and the same rank (5.5) alluded to the fact that in managing children's bad behaviour, parents should advice and train the child. Some children also said that parents must provide the needs of children as well as tell them children motivational stories. The children again maintained that parents should serve as role models to their children. This assertion recorded a total response of 35 and a rank of 10. A rank of 11.5 representing 25 responses shows that parent must not punish children with EBD but rather communicate with them. Even if they will be punished warning should be given first. The children further indicated that parents should have equal treatment for all children. It is evident in Table 9 showing a total response of 10 with a rank of 16.5 .

\section{Summary of Findings}

Some children have been made to think that without corporal punishment children will be putting up bad behaviour. To the respondents, corporal punishment makes the children responsible and do the right thing. It helps the children to learn their mistakes and prevents children from showing bad behaviours as well as serve as deterrent to others. The respondents believe that corporal punishment should be controlled and still feel that other measured should be considered. This is in conformity with what Cooper (1998) said that there are no simple solutions to the problems of adolescent EBDs. As with EBDs in general, multi-dimensional causes require multidimensional interventions. So, there should be a role that schools, teachers and educators of young adolescent should play to help EBD, children to have a positive sense of self.

Majority of the children feel that corporal punishment should be abolished at home and in schools. The reason being that it causes pain and also affect their mental health. According to the children other measures should be considered.

In answering the question, what do you want to say to your parents and teachers regarding how they should manage bad behaviour. The children indicated that parents/ teachers should not punish them but rather give them advice, they should have patience on them and always talk to them. This is in conformity with what Leach (2003) agreed that, subjects such as citizenship and democracy, life skills, guidance and counseling, and personal and social education should be included in the curriculum. This could help improve the behaviour of difficult children.

Parents and teachers need to know the effective use of motivation. Motivation can be re-directed by modeling (examples) and teaching (explanation). It is very imperative that children should be taught positive behaviours instead of inflicting pain on them under the auspices discipline to achieve better behaved children at schools.

\section{Conclusion}

Unlike many other behaviour modification strategies, corporal punishment causes bodily pain on the recipients. Teachers and other educators need to know that whatever ways they think, they need to be very clear about how to discipline a child. As Lenta (2012) said, that since all punishment coerce those subjected to them, they require compelling justification. Teachers, parents and other adults closely involved with children, need to agree on how to discipline children in a consistent and reasonable way. Many children in basic schools and Seniors High Schools are disciplined in an inappropriate manner because most adults including the teachers do not have enough information about behaviour management strategies. Children are excluded from schools and there is less care whether they end up as armed robbers or not. A child is caught pilfering from school and he is excluded to continue pilfering at home without solving his/her problem. We call children lazy without finding the cause of the laziness and help them to solve their problems. Exclusion is not a constructive, educational intervention. Rather it is an unambiguous statement of the school's failure to accommodate the excluded student. Furthermore, it reinforces and provokes negative attitudes towards schools and schooling among those excluded (Cooper et al., cited in Cooper \& Jacobs, 2011). It is therefore required that there should be persuasive justification, in the absence of which corporal punishment should not be prescribed for children (Lenta, 2012).

Grossman (2004) says that ' the list of social skills that the students may lack is very long. They may need to learn to share, to wait their turn, to ask permission, to function cooperatively, to do their share of the work, to acknowledge their mistakes, to smile, to express their anger and resentment in acceptable ways, and so on. 'Students who have a long history of failure and misbehaviour may feel that they are outlaws who have no chance to experience the rewards that other students receive. In this case the teacher needs to make the classroom reward system understandable and accessible. As Smith (2000) noted, in addition to understanding how they can earn the rewards of good grades, these students need to understand how they can earn social benefits of positive behaviour and good social relationships in the classroom.

According to Garbirino (2005), for the purpose of helping the child for positive development, an ecological perspective has much to contribute to the process of understanding corporal punishment. It aids us in seeing the full range of alternative conceptualizations and points us in the direction of multiple strategies for intervention. It provides a kind of checklist to use in thinking about what is happening and what to do about it when faced with developmental problems and social pathologies that may be associated with corporal punishment. 


\section{Recommendation}

It is recommended that, corporal punishment may adversely affect a student's self-image and school achievement and may contribute to disruptive and violent student behaviour (Kilimci, 2009). For this reason, teachers, parents and other educational authorities must be taken through children management programmes or courses to refresh their knowledge on some of the behaviour management techniques. This will help parents and teachers who face problems in child management skills to improve on some basic methods of managing children. Some of the procedures of handling difficult children could be discussed during Parents and Teachers Association meetings. This could help both the parents and teachers solve problems of children without resorting to corporal punishment.

As the children rightly said in this study, parents/ teachers should not punish them but rather give them advice, they should have patience for them and always talk to them. There can be a counselling programme to help children cope with their feelings of anger, which will reduce the amount of aggressive behaviour the children show in class. The only problem will be the ability to sustain the positive effects after the programme has ended. Omizo et al. (1988) and Lochman et al. (1987) reported on counselling programmes delivered by trained specialists to help children aged nine to twelve to cope with their feelings of anger and frustration. Both training programmes were effective at reducing the children's aggressive behaviour whilst the programmes were running, indicating that such programmes may need to be ongoing.

Parents and teachers need to help children learn some basic social skills that will help children on how to interact with their peers and adult as well. When this is done, children will now mingle and interact with their colleagues or even other people both in their school and other places. This is because the children are no longer shy, depressed or afraid of interacting with other people. Hence, helping to reduce some emotional and behaviour difficulties in children.

\section{References}

i. Abrams, B. J. (2005). Becoming a therapeutic teacher for students with emotional and behavioral disorders. Teaching Exceptional Children, 38(2), 40-45.

ii. Agbenyega, J. S. (2006). Corporal punishment in schools of Ghana: Does inclusive education suffer? The Australian Education Researcher, 33(3), 107-122.

iii. American Academy of Child \& Adolescent Psychiatry. (2019). Corporal punishment. Retrieve July 20th, 2019, from https:/ / www.aacap.org

iv. Benatar, D. (1998). "Corporal Punishment”. Social Theory and Practice, 24, 237-260.

v. Cooper, P., \& Jacobs, B. (2011). From inclusion to engagement: Helping children engage with schooling through policy and practice. West Sussex, UK: Wiley-Blackwell.

vi. Cooper, W. M. (1988). An illustrated history of the rod. Hertfordshire, Great Britain: Wordsworth Editions Ltd.

vii. Cryan, J. R. (1995). The banning of corporal punishment. Dimensions of Early Childhood, 23(3), 36-37.

viii. DeNies, Y. (2012). Should your child be spanked at school? In 19 states, it's legal. Retrieve July 5, 2019 from http:/ / abcnews.go.com/ US/ spankingschool-19-states-corporal-

punishmentlegal/ story?id=15932135\#.UFsldY5glqY

ix. Donnelly, M. \& Straus, M. A. (2005). Corporal Punishment of Children in Theoretical Perspective. New Haven and London: Yale University Press.

x. Farooq, U. (2014). Essay on Discipline in School Meaning, Definition \& Concept. Retrieved July 24, 2019 from http:/ / www.studylecturenotes.com/ foundation-of-education/ essay-on-discipline-in-school-meaning-definitionconcept.

xi. Garbarino, J. (2005). Corporal Punishment in Ecological Perspective. In Donnelly, M. and Straus, M.A. (Eds.), Corporal Punishment of Children in Theoretical Perspective. New Haven and London: Yale University Press.

xii. Garbarino, J., E. Guttman, \& Seeley. J. (1986). The Psychologically Battered Child: Strategies for Identification, Assessment, and Intervention. In Donnelly, M. and Straus, M.A. (Eds.), Corporal Punishment of Children in Theoretical Perspective. New Haven and London: Yale University Press.

xiii. George, N. L., George, M. P., Gersten, R., \& Grosenick, J. R. (1995). To leave or to stay? An exploratory study of teachers of students with emotional and behavioural disorders. Remedial \& Special Education, 16(4), 227-236.

xiv. Gershoff, E. T. (2002). Corporal punishment by parents and associated child behaviours and experiences: A metaanalytic and theoretical review. Psychological Bulletin, 128,539-579.

xv. Grossman, H. (2004). Classroom Behaviour Management for Diverse and Inclusive Schools. New York: Rowman and Littlefield publishers, Inc.

xvi. Jenson, W. R., Reavis, H. K., \& Rhode, G. (1998). The tough kid. Longmont Colorado: Sopris West.

xvii. Kilimci, S. (2009). Teachers' perceptions on corporal punishment as a method of discipline in elementary schools. The Journal of International Social Research, 2(8), 242-243.

xviii. Leach, F. (2003). Learning to be violent: The role of the school in developing adolescent gendered behaviour, Compare. A Journal of Comparative and International Education, 33(3), 385-400.

xix. Lenta, P. (2012). Corporal Punishment of Children. Social Theory and Practice, 38(4), 689-716.

xx. Lochman, J. E., Lampron, L. B., Gemmer, T. V., \& Harris, R. (1987). In P. A. Keller \& S. R. Heyman (Eds.), Innovations in clinical practice: A source book. Sarasota, FL: Professional Resource Exchange.

xxi. Omizo M. M., Hershberger, J. M., and Omizo S. A. (1988). Teaching children to cope with anger. Elementary School Guidance and Counselling, 22, 41-46.

xxii. Robison, D. H., Funk, D. C., Beth, A., \& Bush, A. M. (2005). Changing beliefs about corporal punishment: Increasing knowledge about ineffectiveness to build more consistent moral and informational beliefs. Journal of Behavioural Education, 14,117-139. 
xxiii. Rollins, A. J. (2012). Revisiting the Issues of Corporal Punishment in Our Nation's School. Retrieve July 20th, 2019 from https:/ / www.researchgate.net

xxiv. Salmon, H. (2006). Educating students with emotional or behavioral disorders. Law and Disorder, 1, 9-53.

xxv. Smith, M. G. (2000). Secondary teachers' perceptions toward inclusion of students with several disabilities. National Association of Secondary School Principals, NASSP Bulletin, 84(613), 54-60.

xxvi. Wagner, M. (1995). Outcomes for youths with serious emotional disturbance in secondary school and early adulthood. The future of Children: Critical Issues for Children and Youths, 5(4), 90-112.

xxvii. Wagner, M., J. Blackorby, R. Cameto, K. Hebbeler \& L. Newman. (1993). The Transition Experience of Young People with Disabilities. A Summary of Findings from the National Longitudinal Transition Study of Special Education Students. Menlo Park, CA: SRI International. 